\title{
Monitoring of river health using aquatic insects: A study on Jatinga River, North East India
}

\section{Tanushree CHAKRAVARTY, Susmita GUPTA}

Cite this article as:

Chakravarty, T., Gupta, S. (2021). Monitoring of river health using aquatic insects: A study on Jatinga River, North East India. Aquatic Research, 4(4), 363-375. https://doi.org/10.3153/AR21031

Assam University, Department of Ecology and Environmental Science, 788011, Silchar, Assam, India

ORCID IDs of the author(s):

T. C. 0000-0003-4277-7451

S.G. 0000-0002-2738-6789

Submitted: 03.02 .2021

Revision requested: 11.05 .2021

Last revision received: 17.05 .2021

Accepted: 19.05.2021

Published online: 28.08.2021

\begin{abstract}
A biomonitoring study of River Jatinga located in south Assam, north east India was conducted for the first time. The study aimed to evaluate water quality of the river in different stretches using aquatic insect as bioindicators. Insect samples were collected from selected sites of midstream and downstream of the river during monsoon- post monsoon, 2018 and winter- pre monsoon, 2019. A total of 25 families of aquatic insects recorded from 8 orders; Gerridae was eudominant in midstream across all the seasons with highest percentage in winter. Hemiptera, the most diverse group was represented by six families with highest relative abundance. The study found that although both the sites were represented by same functional feeding groups, there were seasonal and spatial variations in the families of insects and their percentage occurrences. All the biotic indices, BMWP ${ }^{\text {THAI }}$, SIGNAL2 scores, EPT \% and HFBI have shown relatively better quality of water of the River Jatinga in the midstream than that in the downstream during monsoon and post monsoon seasons. Presence/absence and abundance of certain insect groups can provide information about health of the river.
\end{abstract}

Keywords: Jatinga River, Bioindicators, Eudominant, Gerridae, Functional feeding group

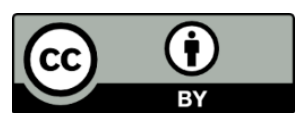

(C) 2021 The Author(s) 


\section{Introduction}

Freshwater systems are rich in biological diversity but these days a majority of the aquatic fauna is under threat because of human activities (Meyer et al., 1999). Millions of people depend on the goods and services of freshwater systems like, rivers, streams, lakes, wetlands etc. and daily supply of clean fresh water is needed in every human existence (Barathy et al., 2021). Unfortunately, in some areas people still consume polluted and contaminated water without any treatment (Arthington et al., 2010). Currently, surface water pollution is increasing and as a result human and ecosystem health is deteriorating gradually (Aazami et al., 2020). Hence assessment of river health is very essential as organic and inorganic pollution is on rise affecting human health as well as freshwater faunal diversity. Biomonitoring is the "systematic use of living organisms or their responses to determine the condition or changes of the environment" (Oertel and Salanki, 2003). Many countries have a long history of using macroinvertebrates to monitor the ecological status of river ecosystems (Hellawell, 1986; Li et al., 2010; Birk et al., 2012; Carter et al., 2017; Musonge et al., 2020; Akyildiz and Duran, 2021; Eriksen et al., 2021). Studies on the potential use of benthic macroinvertebrates as bioindicators for river ecosystems also have been broadly reported in literature (Rosenberg and Resh, 1993; Mustow, 2002; Ganguly et al., 2018; Aazami et al., 2019; Mahmoud and Riad, 2020).

Aquatic insects are important component of benthic macroinvertebrates who spend their life or some part of their life in water. Being highly specialized they represent less than $1 \%$ of the total animal diversity (Pennak, 1978). They are known to play a very significant role in the processing and cycling of nutrients as they belong to several specialized feeding groups such as shredders, filter feeders, deposit collectors, and predators (Rosenberg and Resh, 1993). Some of the aquatic insects are very sensitive to pollution, while others are tolerant and many species are very susceptible to pollution or alteration of their habitat (Merritt and Cummins, 1996). Macroinvertebrates are vital indicators of the changes in freshwater habitats and family-level identification can be valuable in evaluation of water quality (Aazami et al., 2020). In northeast India though surface water pollution is on rise, a few studies on biomonitoring of streams and rivers have been recorded (Takhelmayum et al., 2013; Barman and Gupta, 2015; Marwein and Gupta, 2018).

The River Jatinga originating from the Jatinga village, Dima Hasao district of Assam flows all the way through the western boundary of the Barail Wildlife Sanctuary, Assam and joins River Barak, the second largest river of Assam (Figure 1). The district comprises geographic area of 3786 sq. km and
$57.86 \%$ of it is under forest cover (FSI, 2019). The Tea based agroforestry at the riverbank of midstream provides employment opportunities to the local people to sustain their livelihoods. Cultivation of seasonal crops at the bank and catchment area of the river strengthen the economic status of the riverine villagers. Since there is paucity of data on this important river of south Assam, we have attempted to generate baseline information on the aquatic insect community of the river and monitor water quality using aquatic insects as bioindicators. Various biotic indices such as Biological Monitoring Working Party Score (BMWP ${ }^{\mathrm{THAI}}$ ), Average Score per Taxon (ASPT ${ }^{\mathrm{THAI}}$ ), percentage of Ephemeroptera, Plecoptera, Trichoptera (\%EPT), Hilsenhoff family biotic index (HFBI) and Stream Invertebrate Grade Number Average Level (SIGNAL2) were used. It is expected that this study would give insight of the water quality of the river, which is supposed to be pristine.

\section{Material and Methods}

\section{Study Area and Collection of Aquatic Insects}

The River Jatinga flows through evergreen and deciduous forest area with varied flora and fauna. The selected study sites of River Jatinga are midstream of the river at Damcherra in Cachar district and downstream at Borkhola in Cachar district (Table 1). The selected study sites, midstream and downstream of the river (Figure 2), on both the sites have hillocks and there are small villages in the foothills. Villagers are mostly dependent on the river as a source of their revenue generation and enjoy the ecosystem services of the river. River bank is mostly utilized for agricultural practices in downstream. Jhum cultivation is the usual practice in the surrounding hilly region of midstream area and also a few tea gardens nearby. Midstream site is also rich in riparian vegetation.

Aquatic insects were collected by using "kick-net method" and "all out search method" from the midstream and downstream of River Jatinga during monsoon, post monsoon 2018 and winter, pre monsoon 2019. Sampling was done by taking three, 1-minute kick-net samples (mesh opening: $180 \mu \mathrm{m}$; area $1 \mathrm{~m}^{2}$ ). The kick-net is held against water current and an area of $\left(1 \mathrm{~m}^{2}\right)$ in front of the net is disturbed for one minute (Brittain, 1974; Subramanian and Sivaramakrishnan, 2007). All out search method is used when water flows through boulder and cobble with high turbulence. Aquatic insects were collected from 10 square meter area for one hour. Within the sampling area, aquatic insects were searched in all the possible substrata such as boulders, cobbles, leaf litter and dead wood. A sable hairbrush or forcep was used for collection of 
all samples (Subramanian and Sivaramakrishnan, 2007). After collection, insects were preserved in $70 \%$ ethanol. Collected samples were examined under a motic stereozoom microscope and identified upto family using standard taxonomic literature (Merritt and Cummins, 1996; Subramanian and Sivaramakrishnan, 2007; Thirumalai, 1999; Choate, 2003; Bouchard, 2009; Boonsoong and Braasch, 2013).

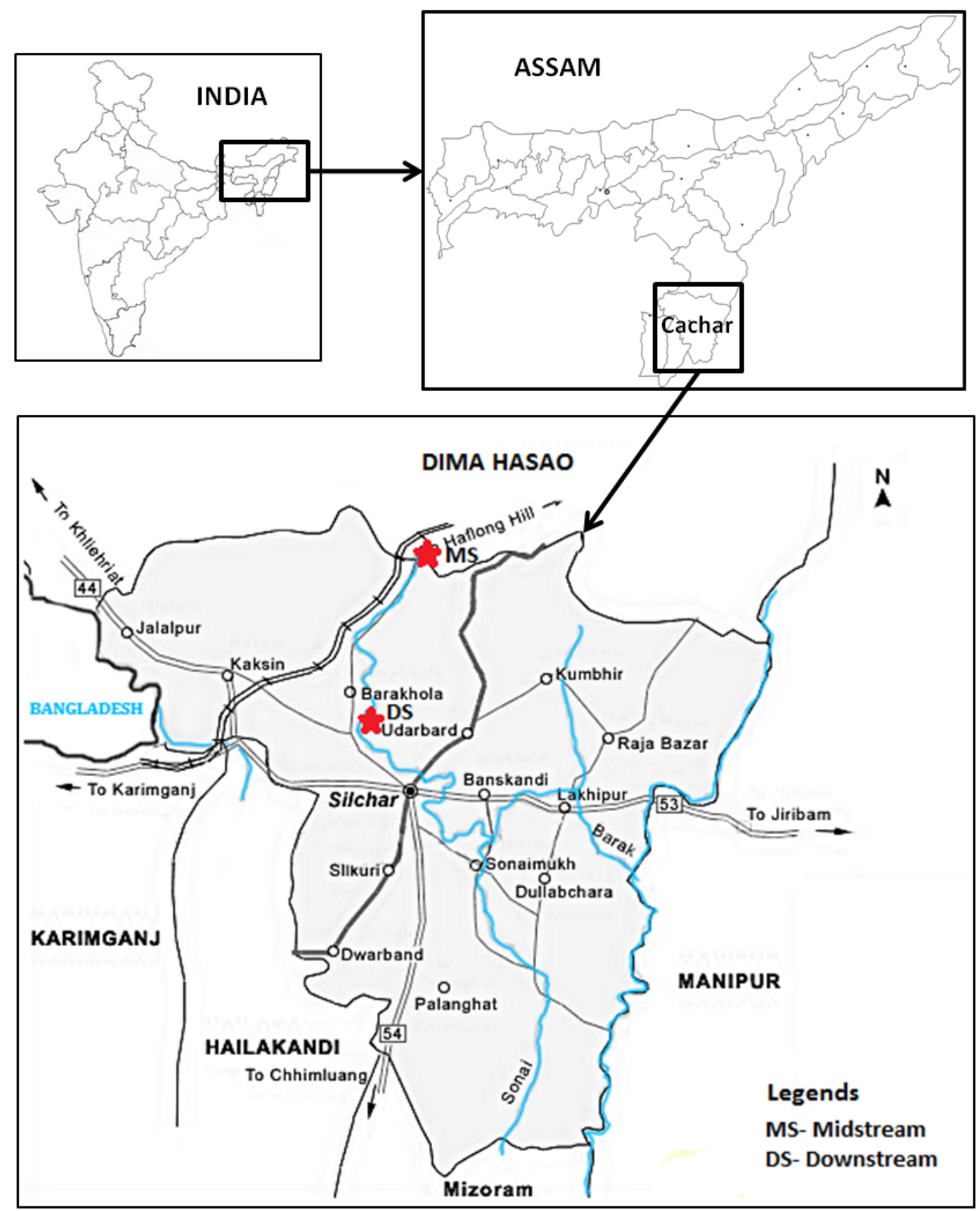

Figure 1. Map showing midstream and downstream of River Jatinga. Map not to scale. 

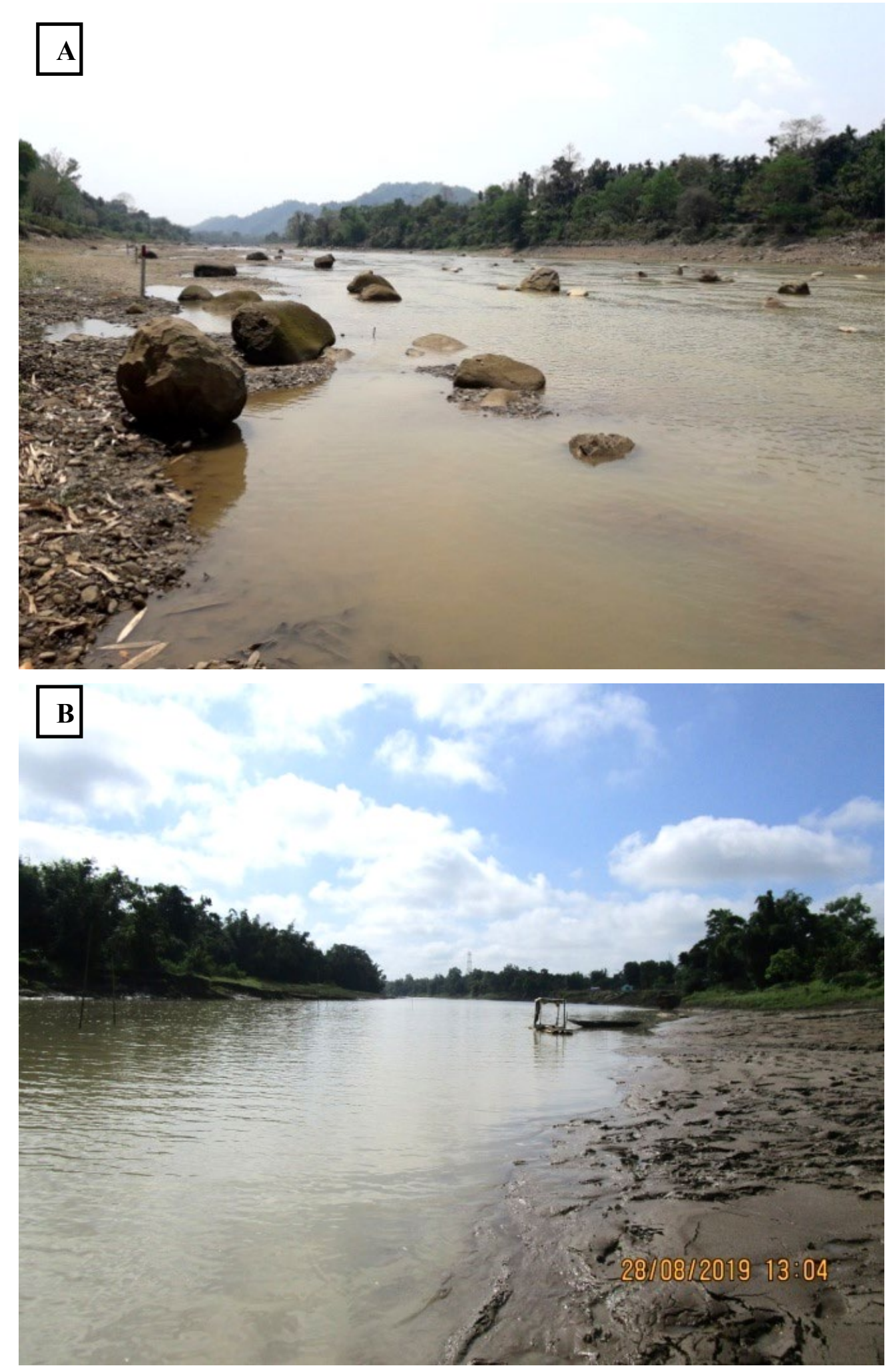

Figure 2. Photographs of midstream and downstream of River Jatinga. [A] Midstream, [B] Downstream. 
Table 1. Description of midstream and downstream of River Jatinga

\begin{tabular}{|c|c|c|c|c|}
\hline Site & $\begin{array}{l}\text { Lattitude, longitude } \\
\text { and altitude }\end{array}$ & Riparian vegetation & Habitat types (mm) & Riverine settlement type \\
\hline $\begin{array}{l}\text { Midstream } \\
\text { (Damcherra, } \\
\text { Cachar } \\
\text { District) }\end{array}$ & $\begin{array}{l}\text { N } 25^{\circ} 00^{\prime} 6.67^{\prime \prime} \\
\text { E } 92^{2} 45^{\prime} 0.70^{\prime \prime} \\
28 \text { m MSL. }\end{array}$ & $\begin{array}{l}\text { Camellia sinensis, Polygonum } \\
\text { sp., Melia azadirach, Colocasia } \\
\text { sp., Fern sp., various types of } \\
\text { orchid species, various grass } \\
\text { species, Bambusa sp.etc }\end{array}$ & $\begin{array}{c}\text { Cobbles }(\leq 82 \mathrm{~mm}) \text {, pebbles } \\
(\leq 34 \mathrm{~mm}) \text {, granule }(\leq 3 \mathrm{~mm} \text {, } \\
\text { sand }(\leq 2 \mathrm{~mm}) \text {, silt }(\leq 0.06 \\
\mathrm{mm}) \text {, clay }(\leq 0.004 \mathrm{~mm}) \text { and } \\
\text { few boulder }(\leq 390 \mathrm{~mm})\end{array}$ & $\begin{array}{l}\text { Hillock, Tea garden, home } \\
\text { garden, river bank agricultural } \\
\text { cultivation (Cucurbitaceae, } \\
\text { Solanaceae, Liguminosae etc.) }\end{array}$ \\
\hline $\begin{array}{l}\text { Downstream } \\
\text { (Borkhola, } \\
\text { Cachar district) }\end{array}$ & $\begin{array}{l}\text { N } 24^{\circ} 55^{\prime} 52.1^{\prime \prime} \\
\text { E } 92^{\circ} 45^{\prime} 15.2^{\prime \prime} \\
18 \text { m MSL. }\end{array}$ & $\begin{array}{l}\text { Bambusa sp., various types of } \\
\text { agricultural crops, various types } \\
\text { of herbs, shrubs and trees. }\end{array}$ & Sand, silt and clay $(\leq 2 \mathrm{~mm})$ & $\begin{array}{c}\text { River bank agricultural } \\
\text { cultivation (Cucurbitaceae, } \\
\text { Solanaceae, Liguminosae, } \\
\text { Brassicaceae, leafy greens, root } \\
\text { crop etc.), home garden, grazing } \\
\text { land, wet paddy cultivation. }\end{array}$ \\
\hline
\end{tabular}

\section{Data Analysis}

The dominance status of different families was worked out following Engelmann's scale based on relative abundance (Engelmann, 1978). Diversity indices such as Shannon-wiener diversity index and Margalef's richness index were carried out using PAST 3.14 software version for Windows 10 (Adu and Oyeniyi, 2019).

The biological monitoring working party score (BMWP ${ }^{\mathrm{THAI}}$ ) can be obtained by summing the individual scores of all families present. Score values for individual families reflect their pollution tolerance (Mandaville, 2002). The Average Score per Taxon (ASPT ${ }^{\mathrm{THAI}}$ ) is calculated by dividing the score by the total number of scoring taxa (Mandaville, 2002). A high ASPT $^{\mathrm{THAI}}$ usually characterizes clean sites with relatively large numbers of high scoring taxa. Stream Invertebrate Grade Number-Average Level (SIGNAL 2) was calculated by total grade of aquatic insect families multiplied by the weight factor divided by total weight factor of aquatic insect family. A weight factor was determined for each type of macroinvertebrate, considering the number of specimens collected (Chessman, 2003). The percentage occurrence of Ephemeroptera, Plecoptera and Trichoptera (\% EPT) were also calculated (Subramanian and Sivaramakrishnan, 2007). Hillsenhoff family biotic index (HFBI) was developed by Hilsenhoff (Hilsenhoff, 1988) to summarize the various tolerances of the benthic arthropod community with a single value. Tolerance values for families range from $0-10$. Value increases as water quality decreases (Table 2).

\section{Results and Discussion}

A total of 25 families of aquatic insects belonging to 8 orders were recorded in both midstream and downstream during the study period (Table 3 ). The number of families recorded in midstream and downstream is 20 and 14 respectively. Aphelocheiridae, Notonectidae, Gyrinidae, Psephenidae, Ephemeridae, Lepidostomatidae, Perlidae, Gomphidae, Euphaeidae, Tipulidae and Corydalidae were found only in midstream and Caenidae, Elmidae, Dytiscidae and Veliidae were recorded only in downstream. The common aquatic insect families found in both midstream and downstream are Gyrinidae, Corixidae, Dytiscidae, Hydrophilidae, Baetidae, Heptageniidae, Hydropsychidae, Libellulidae, Culicidae and Chironomidae. Hemiptera, the most diverse group represented by six families was followed by Coleoptera, Ephemeroptera and Odonata. Highest number of Hemipteran families and their highest relative abundance were also recorded in Moirang River of Manipur, India (Takhelmayum et al., 2013)

Table 2. Evaluation of water quality using family level biotic index (Hilsenhoff 1988)

\begin{tabular}{l|l|l}
\hline HFBI & Water quality & Degree of organic pollution \\
\hline $0.00-3.75$ & Excellent & Organic pollution unlikely \\
$3.76-4.25$ & Very good & Possible slight organic pollution \\
$4.26-5.00$ & Good & Some organic pollution probable \\
$5.01-5.75$ & Fair & Fairly substantial pollution likely \\
$5.76-6.50$ & Fairly poor & Substantial pollution likely \\
$6.51-7.25$ & Poor & Very substantial pollution likely \\
$7.26-10.00$ & Very poor & Severe organic pollution likely \\
\hline
\end{tabular}

During monsoon season, 7 orders, 8 families and 46 individuals of aquatic insects were found in midstream and 3 orders, 4 families and 15 individuals in downstream. Again, during post monsoon a total of 6 orders, 7 families and 102 individuals were found in midstream and 4 orders, 5 families and 34 individuals in downstream. In winter, 4 orders, 7 families and 76 individuals were found in midstream while 4 orders, 6 families and 98 individuals found in downstream. During pre 
monsoon, 4 orders, 6 families and 36 individuals were found in midstream and 5 orders, 8 families and 40 individuals in downstream (Figure 3). Both highest and lowest number of order and family were found in monsoon, highest in midstream and lowest in downstream. Density was found highest in midstream during post monsoon and lowest in downstream during monsoon season (Figure 3). Takhelmayum et al. (2013) in a study on River Moirang found that highest density was directly proportional to the seasonal fluctuations of water level and availability of food resources. According to Arunachalam et al. (1991), leaf packs and algal biomass are the high-quality food resources for most of the benthic macroinvertebrates and very important energy source for stream communities. The highest insect density in the post monsoon in midstream could be attributed to high algal biomass in the stream in the same season. High temperature of water and air during post monsoon might have also played a role. The seasonal differences in the abundance of aquatic insects in streams are largely governed by temperature (Gupta and Michael, 1983). The distribution, abundance and diversity of the aquatic insects are affected by intra and inter specific competition plus tolerance capacity of organisms to changing environmental variables of water (Habib and Yousuf, 2012).

Shannon-Wiener diversity index of both the midstream and downstream ranged between 1.02-1.47 during the study period (Figure 5). In the midstream, it ranged from 1.05-1.31, where highest value recorded during pre monsoon and lowest recorded in post monsoon. In the downstream, Shannon-Wiener diversity index $\left(\mathrm{H}^{\prime}\right)$ ranged from $1.02-1.47$ where, highest value recorded during pre monsoon and lowest recorded in the monsoon season. Values above 3.0 indicate stable habitat and values under 1.0 indicate that there is pollution of habitat structure (Turkmen and Kazanci, 2010). The diversity index value greater than 1 in both the sites during the study period indicated moderate pollution of the river as seen in other studies (Takhelmayum et al., 2013; Sandin and Johnson, 2000). Margalef's richness index (Figure 5) ranged from 2.99-5.25 where highest score recorded during winter and lowest score recorded in the post monsoon season in the midstream while in the downstream it ranged from 2.51-4.37 where, highest score recorded during pre monsoon and lowest in the winter season. Score more than 3 indicates 'clean' condition; score less than 1 indicates 'severe' pollution and intermediate score indicates 'moderate' pollution of water (Lenat et al., 1980).

Based on Engelmann scale (Engelmann, 1978) (Table 3), in all the four seasons in the midstream Gerridae was eudominant in all the seasons ranging from $58.33 \%$ to $72.5 \%$ followed by Heptageniidae (13.04\%) while Corixidae recorded eudominant in the downstream followed by Veliidae as dominant during monsoon. Eudominance of Gerridae in the midstream in all the seasons is related to their wide preference of laying and attaching eggs to the vegetation and stone surface etc. Moreover, during hibernation, Gerridae usually use leaf litter, rocks and other sheltered sites near water (Stonedahl and Lattin, 1982). Thus, Gerridae preferred midstream because of the substratum type and rich riparian vegetation. Although Corixidae was eudominant in the monsoon in the downstream, in the post monsoon it was replaced by Chironomidae as eudominant group followed by Corixidae as dominant. However, in the winter season Corixidae regained its eudominant status in the downstream (Table 3 ).

Aquatic insects were classified in to functional feeding groups (FFG) on the basis of ecosystem functioning, as they belong to several specialized feeding groups and from their relative abundance, we assess the impact of anthropogenic activity on freshwater ecosystem (Marsese et al., 2014). The FFG of the stream insects show deviation across habitat (Subramanian and Sivaramakrishnan, 2005). In the midstream, the main FFG was predators $(67.65 \%-91.25 \%)$ followed by scrapers $(13.04 \%-22.55 \%)$ whereas in the downstream piercers-herbivores, predators/scrapers $(17.65 \%-$ $68.37 \%$ ) was the main functional feeding groups followed by collectors-gatherers and filterers, predators $(8.16 \%-64.71 \%)$ during study periods (Table 4). The predators were represented by Gerridae, Notonectidae, Mesoveliidae, Veliidae, Aphelocheiridae, Dytiscidae, Gyrinidae, Perlidae, Gomphidae, Libellulidae, Euphaeidae, Corydalidae and scrapers were represented by Psephenidae and Heptageniidae. Although both the sites were represented by same FFGs, there were seasonal and spatial variations in their percentage occurrences. Thus, meager percentage occurrence of scrapers $(6.67 \%)$ (Table 4) in the downstream in monsoon and absence in other seasons can be explained by the fact that downstream habitat is always dominated by sand and their mouthparts are not equipped for collection of food from such habitat. According to Brasil et al. (2014), their mouthparts are specialized for removing materials adhered to the substrate like stones/boulders found in the upper stretches. The study found that the relative abundance of the families of order Hemiptera was found highest and mostly represented by predators as revealed in other studies also in northeast India (Takhelmayum et al., 2013; Barman and Gupta, 2015). Hemipterans are successful in all the possible aquatic environments as they possess oar like hind legs for swimming, can walk on surface water, breathe by the means of an air store and have prominent eyes (Barman and Gupta, 2015). 


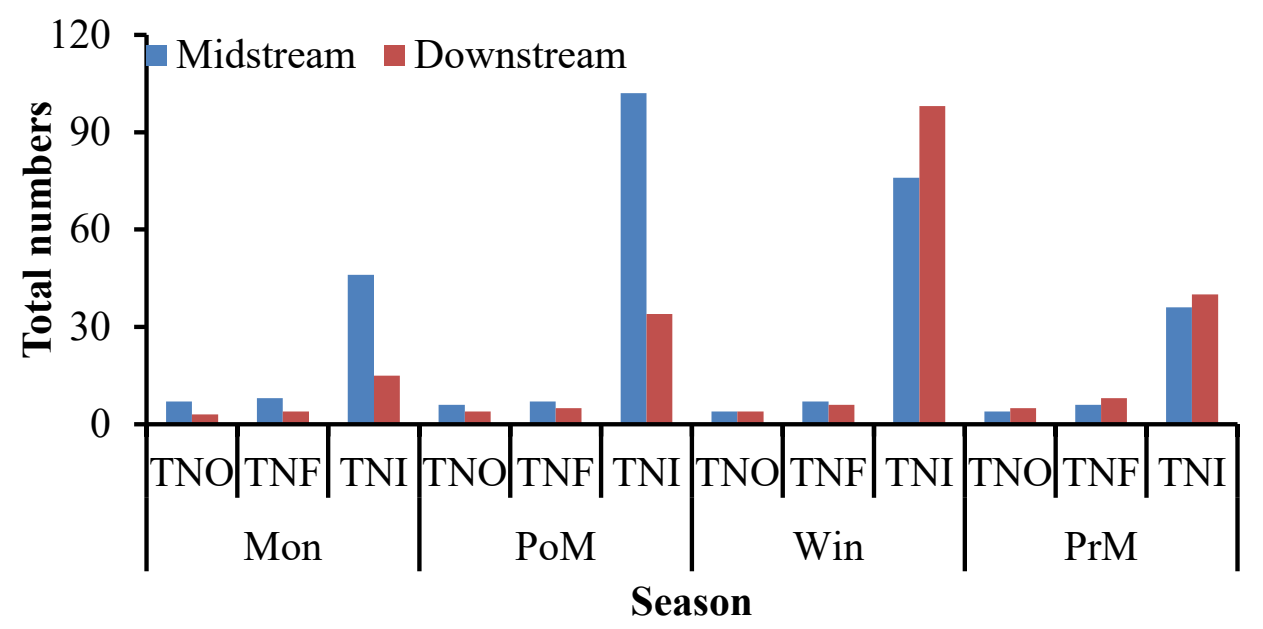

Figure 3. Total number of order, family and individuals of aquatic insects of River Jatinga during 2018-2019; Mon- Monsoon, PoM- Post monsoon, Win- Winter, PrM- Pre monsoon. TNO- Total number of order, TNF- Total number of family and TNI- Total number of individual.

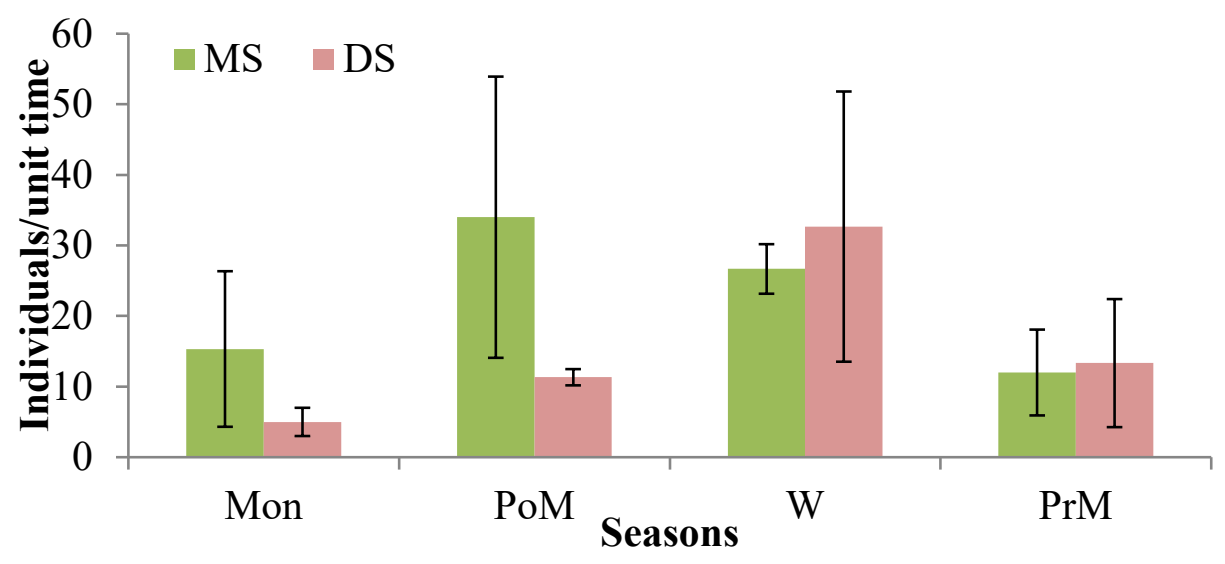

Figure 4. Seasonal insect density (mean \pm SD) in midstream and downstream of Jatinga River during 2018-2019.

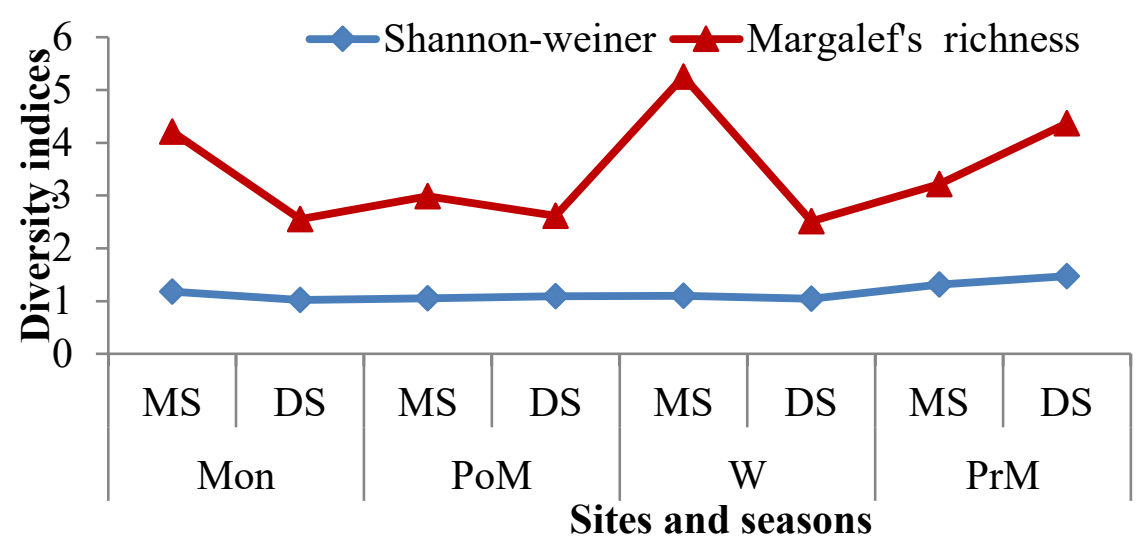

Figure 5. Seasonal variations of diversity indices of aquatic insects of the midstream and downstream of Jatinga River during 2018-2019. 
BMWP ${ }^{\text {THAI }}$ score indicated 'moderate' water condition in midstream and 'poor' condition at downstream during monsoon, post monsoon and winter season whereas, 'poor' water condition recorded at midstream and 'moderate' condition recorded in downstream during the pre monsoon season (Table 5). Presence of good number of EPT groups in midstream revealed good condition of water quality during study period, as a result midstream found high BMWP ${ }^{\mathrm{THAI}}$ score than downstream (Chaw et al., 2018). The BMWP ${ }^{\mathrm{THAI}}$ score provides single value, at the family level of the aquatic insect tolerance to pollution. The greater their tolerance towards pollution the lower is their BMWP ${ }^{\mathrm{THAI}}$ score (Mustow, 2002; Mandaville, 2002).

'Clean water' recorded at both the midstream and downstream during monsoon season as per ASPT ${ }^{\mathrm{THAI}}$ score. During post monsoon and winter season, midstream and downstream indicated 'doubtful quality' and 'probable moderate pollution' respectively. But in the pre monsoon season midstream recorded 'clean water' and downstream recorded 'severe pollution' (Table 5). If ASPT ${ }^{\mathrm{THAI}}$ score is greater than 6 then 'clean water', 5-6 'doubtful quality', 4-5 'probable moderate pollution' and less than 4 then 'probable severe pollution' (Mandaville, 2002). SIGNAL2 score indicated 'healthy habitat' for midstream and 'severe pollution' for downstream in both monsoon and post monsoon season. Similarly, it indicated 'Moderate' and 'severe pollution' at midstream and downstream during winter and pre monsoon, respectively (Table 5). A SIGNAL2 score gives an indication of water quality in the river from which the sample was collected. Each type of macroinvertebrate has a grade number between 1 and 10, low-grade number indicates macroinvertebrate is tolerant towards pollution and higher the number, the greater the average sensitivity (Chessman, 2003).

The \% of EPT recorded 'moderate' condition of the water, $26.09 \%$ in monsoon and $29.41 \%$ in post monsoon in the midstream while 'poor' condition $6.7 \%$ in monsoon and $5.9 \%$ in post monsoon in the downstream (Table 5). Studies on three streams of Terengganu, Malaysia also revealed good quality of river water by the presence of major aquatic insect taxa i.e. Ephemeroptera, Plecoptera and Trichoptera (Wahizatul et al., 2011; Azmi et al., 2018). Presence of high \% of EPT communities represent a good quality stream as EPT communities are prevalent in undisturbed streams and exhibit low tolerance towards water pollution (Chaw et al., 2018). In the present study, \% of EPT in the midstream is low though compared to downstream it is higher indicating relatively better status of water quality in the midstream. HFBI recorded 'good' condition of water quality in the midstream during monsoon and post monsoon season (4.46 and 4.83), while 'fairly poor' and 'poor' (6 and 7.12) water quality recorded in downstream during the monsoon and post monsoon season respectively. 'Fair' (5.06-5.5) water condition recorded at both the midstream and downstream in the winter and pre monsoon season respectively (Table 5).

All the biotic indices such as BMWP ${ }^{\mathrm{THAI}}$ and SIGNAL2 scores, EPT \% and HFBI have shown relatively better quality of water of the River Jatinga in the midstream than that in the downstream during monsoon and post monsoon seasons. Sand mining activity nearly 5 kilometers upwards from the downstream might have impacted the water quality of the downstream. Sand mining not only deteriorate water quality but also change the richness and diversity of aquatic community (Bhattacharya et al., 2019). Other anthropogenic activities of the villagers include domestic work, fishing, recreational activities, input of agricultural waste and pesticide from the riverbank agricultural activities. In the winter and pre monsoon, water quality was seen to have further deteriorated in both the stretches, which may be due to lack of rainfall and thus nutrients concentrated. 
Aquat Res 4(4), 363-375 (2021) • https://doi.org/10.3153/AR21031

Table 3. Seasonal variations in aquatic insect families, functional feeding groups and dominance status (Engelmann, 1978) of the midstream (MS) and downstream (DS) of River Jatinga during 2018-2019

\begin{tabular}{|c|c|c|c|c|c|c|c|c|c|c|}
\hline \multirow{2}{*}{ Order } & \multirow{2}{*}{ Family } & \multirow{2}{*}{ FFG } & \multicolumn{4}{|c|}{ Midstream } & \multicolumn{4}{|c|}{ Downstream } \\
\hline & & & Mon & PoM & $\mathbf{W}$ & PrM & Mon & PoM & $\mathbf{W}$ & PrM \\
\hline \multirow{6}{*}{ Hemiptera } & Gerridae & $\operatorname{Pr}$ & $67.39 \%(\mathrm{ED})$ & $65.69 \%(\mathrm{ED})$ & $72.5 \%(\mathrm{ED})$ & $58.33 \%$ ED) & - & $5.88 \%(\mathrm{SD})$ & - & $5 \%(\mathrm{SD})$ \\
\hline & Notonectidae & $\operatorname{Pr}$ & - & - & $1.25 \%(\mathrm{R})$ & $8.33 \%(\mathrm{SD})$ & - & - & - & - \\
\hline & Mesoveliidae & $\operatorname{Pr}$ & - & - & - & - & - & - & - & $2.50 \%(\mathrm{R})$ \\
\hline & Veliidae & $\operatorname{Pr}$ & - & - & - & - & $26.67 \%$ (D) & - & - & - \\
\hline & Aphelocheiridae & $\operatorname{Pr}$ & - & - & $2.5 \%(\mathrm{R})$ & $8.33 \%(\mathrm{SD})$ & - & - & - & - \\
\hline & Corixidae & $\mathrm{Pc}-\mathrm{Hb}, \mathrm{Pr} / \mathrm{Sc}$ & - & - & $2.5 \%(\mathrm{R})$ & - & $60 \%(\mathrm{ED})$ & $17.65 \%(\mathrm{D})$ & $68.37 \%(\mathrm{ED})$ & $50 \%(\mathrm{ED})$ \\
\hline \multirow{5}{*}{ Coleoptera } & Dytiscidae & $\operatorname{Pr}(\mathrm{L}$ and $\mathrm{A})$ & - & - & - & - & - & - & $4.08 \%(\mathrm{SD})$ & - \\
\hline & Gyrinidae & $\operatorname{Pr}(\mathrm{L}$ and $\mathrm{A})$ & - & - & $12.5 \%(\mathrm{D})$ & - & - & - & - & - \\
\hline & Psephenidae & $\mathrm{Sc}(\mathrm{L})$ & - & $0.98 \%(\mathrm{SR})$ & - & - & - & - & - & - \\
\hline & Elmidae & $\begin{array}{l}\mathrm{CG}, \mathrm{Sc}, \mathrm{Sh}-\mathrm{Hb} \\
\text { (L and A) }\end{array}$ & - & - & - & - & - & - & - & $2.50 \%(\mathrm{R})$ \\
\hline & Hydrophilidae & $\operatorname{Pr}(\mathrm{L}), \mathrm{CG}(\mathrm{A})$ & $2.17 \%(\mathrm{R})$ & - & - & - & $6.67 \%(\mathrm{SD})$ & - & $15.31 \%(\mathrm{D})$ & $20 \%(\mathrm{SD})$ \\
\hline \multirow{4}{*}{ Ephemeroptera } & Baetidae & $\mathrm{CG}$ & $4.35 \%(\mathrm{SD})$ & $5.88 \%(\mathrm{SD})$ & - & $13.89 \%(\mathrm{D})$ & - & - & - & $2.50 \%(\mathrm{R})$ \\
\hline & Ephemeridae & $\mathrm{CG}$ & - & - & $1.25 \%(\mathrm{R})$ & - & - & - & - & - \\
\hline & Caenidae & $\mathrm{CG}$ & - & - & - & - & - & - & $2.04 \%(\mathrm{R})$ & - \\
\hline & Heptageniidae & Sc & $13.04 \%(\mathrm{D})$ & $21.57 \%(\mathrm{D})$ & - & - & $6.67 \%(\mathrm{SD})$ & - & - & - \\
\hline \multirow{2}{*}{ Trichoptera } & Hydropsychidae & $\mathrm{Ft}, \mathrm{Pr}$ and $\mathrm{Sc}(\mathrm{S})$ & $2.17 \%(\mathrm{R})$ & $1.96 \%(\mathrm{R})$ & - & - & - & $5.88 \%(\mathrm{SD})$ & - & - \\
\hline & $\begin{array}{l}\text { Lepidosto- } \\
\text { matidae }\end{array}$ & Sh-Dt & - & - & - & $2.78 \%(\mathrm{R})$ & - & - & - & - \\
\hline Plecoptera & Perlidae & $\operatorname{Pr}$ & $6.52 \%(\mathrm{SD})$ & - & - & - & - & - & - & - \\
\hline \multirow{3}{*}{ Odonata } & Gomphidae & $\operatorname{Pr}$ & - & - & $1.25 \%(\mathrm{R})$ & - & - & - & - & - \\
\hline & Libellulidae & $\operatorname{Pr}$ & - & $1.96 \%(\mathrm{R})$ & $1.25 \%(\mathrm{R})$ & $8.33 \%(\mathrm{SD})$ & - & $5.88 \%(\mathrm{SD})$ & - & $2.50 \%(\mathrm{R})$ \\
\hline & Euphaeidae & $\mathrm{Pr}$ & $2.17 \%(\mathrm{R})$ & - & - & - & - & - & - & - \\
\hline Megaloptera & Corydalidae & $\mathrm{Pr}$ & $2.17 \%(\mathrm{R})$ & - & - & - & - & - & - & - \\
\hline \multirow{3}{*}{ Diptera } & Tipulidae & Sh-Dt, CG & - & - & $\begin{array}{l}2.5 \% \\
(\mathrm{R})\end{array}$ & - & - & - & - & - \\
\hline & Culicidae & Ft and $\mathrm{CG}$ & - & - & $1.25 \%(\mathrm{R})$ & - & - & - & $2.04 \%(\mathrm{R})$ & - \\
\hline & Chironomidae & $\mathrm{CG}$ and $\mathrm{Ft}, \mathrm{Pr}$ & - & $1.96 \%(\mathrm{R})$ & $1.25 \%(\mathrm{R})$ & - & - & $64.71 \%(\mathrm{ED})$ & $8.16 \%(\mathrm{SD})$ & $15 \%$ (D) \\
\hline
\end{tabular}

Mon- Monsoon, PoM- Postmonsoon, W-Winter, PrM-Premonsoon, FFG- Functional Feeding Group, RA $<1.0 \%=$ Subrecedent $(\mathrm{SR}) ; 1.1 \%-3.1 \%=\mathrm{Recedent}(\mathrm{R}) ; 3.2 \%-10.0 \%=$ Subdominant (SD); $10.1 \%-31.6 \%=$ Dominant (D); $31.7 \%$ - 100\% = Eudominant (ED), Pr- Predators, Pc- Piercers, Hb- Herbivores, Sc- Scrapers, CG- Collectors-Gatherers, L-

Larvae, A- Adult, Sh- Shredders, Ft- Filterers, Dt- Detritivores 
Aquat Res 4(4), 363-375 (2021) • https://doi.org/10.3153/AR21031

Table 4. Functional feeding groups (\%) of midstream and downstream during study period (2018-2019)

\begin{tabular}{|c|c|c|c|c|c|c|c|c|}
\hline \multirow{2}{*}{ FFG } & \multicolumn{2}{|c|}{ Mon } & \multicolumn{2}{|c|}{ PoM } & \multicolumn{2}{|c|}{$\mathbf{W}$} & \multicolumn{2}{|c|}{ PrM } \\
\hline & MS & DS & MS & DS & MS & DS & MS & DS \\
\hline $\operatorname{Pr}$ & 78.26 & 26.67 & 67.65 & 11.76 & 91.25 & 4.08 & 83.33 & 10.00 \\
\hline $\mathrm{Pc}-\mathrm{hb}, \mathrm{Pr} / \mathrm{Sc}$ & 0.00 & 60.00 & 0.00 & 17.65 & 2.50 & 68.37 & 0.00 & 50.00 \\
\hline $\mathrm{CG}, \mathrm{Sc}, \mathrm{Sh}-\mathrm{Hb}$ & 0.00 & 0.00 & 0.00 & 0.00 & 0.00 & 0.00 & 0.00 & 2.50 \\
\hline $\mathrm{Pr}, \mathrm{CG}$ & 2.17 & 6.67 & 0.00 & 0.00 & 0.00 & 0.00 & 0.00 & 20.00 \\
\hline $\mathrm{CG}$ & 4.35 & 0.00 & 5.88 & 0.00 & 1.25 & 17.35 & 13.89 & 2.50 \\
\hline $\mathrm{Ft}, \mathrm{Pr}$ and $\mathrm{Sc}$ & 2.17 & 0.00 & 1.96 & 5.88 & 0.00 & 0.00 & 0.00 & 0.00 \\
\hline Sh-Dt & 0.00 & 0.00 & 0.00 & 0.00 & 0.00 & 0.00 & 2.78 & 0.00 \\
\hline Sh-Dt, CG & 0.00 & 0.00 & 0.00 & 0.00 & 2.50 & 0.00 & 0.00 & 0.00 \\
\hline Ft and $\mathrm{CG}$ & 0.00 & 0.00 & 0.00 & 0.00 & 1.25 & 2.04 & 0.00 & 0.00 \\
\hline $\mathrm{CG}$ and $\mathrm{Ft}, \mathrm{Pr}$ & 0.00 & 0.00 & 1.96 & 64.71 & 1.25 & 8.16 & 0.00 & 15.00 \\
\hline
\end{tabular}

Mon- Monsoon, PoM- Postmonsoon, W-Winter, PrM-Premonsoon, FFG- Functional Feeding Group, Pr- Predators, Pc- Piercers, Hb- Herbivores, Sc- Scrapers, CG-

Collectors-Gatherers, Sh- Shredders, Ft- Filterers, Dt- Detritivores. Midstream (MS), Downstream (DS).

Table 5. Seasonal variations in biomonitoring scores in midstream (MS) and downstream (DS) of River Jatinga during 2018-2019

\begin{tabular}{|c|c|c|c|c|c|c|c|c|c|c|c|c|}
\hline \multirow[t]{2}{*}{ Season } & \multirow[t]{2}{*}{ Site } & \multicolumn{2}{|r|}{$\mathrm{BMWP}^{\mathrm{THAI}}$} & \multicolumn{2}{|r|}{$\mathrm{ASPT}^{\mathrm{THAI}}$} & \multicolumn{2}{|c|}{ SIGNAL 2} & \multicolumn{2}{|c|}{$\% \mathrm{EPT}$} & \multicolumn{3}{|c|}{ HFBI } \\
\hline & & Score & Biological class/Remark & Score & Biological class/Remark & Score & Remark & Score & Remark & Score & $\begin{array}{l}\text { Water } \\
\text { quality }\end{array}$ & $\begin{array}{l}\text { Degree of organic } \\
\text { pollution }\end{array}$ \\
\hline \multirow{2}{*}{ Monsoon } & MS & 58 & Moderate & 7.3 & Clean water & 6.6 & Healthy habitat & 26.09 & Moderate & 4.46 & Good & $\begin{array}{l}\text { Some organic } \\
\text { pollution probable }\end{array}$ \\
\hline & DS & 30 & Poor & 7.5 & Clean water & 3.4 & Severe pollution & 6.7 & Poor & 6 & $\begin{array}{l}\text { Fairly } \\
\text { poor }\end{array}$ & $\begin{array}{l}\text { Substantial pollution } \\
\text { likely }\end{array}$ \\
\hline \multirow{2}{*}{$\begin{array}{c}\text { Post } \\
\text { monsoon }\end{array}$} & MS & 42 & Moderate & 6 & Doubtful quality & 6.1 & Healthy habitat & 29.41 & Moderate & 4.83 & Good & $\begin{array}{l}\text { Some organic } \\
\text { pollution probable }\end{array}$ \\
\hline & DS & 25 & Poor & 5 & Probable moderate pollution & 3.2 & Severe pollution & 5.9 & Poor & 7.12 & Poor & $\begin{array}{l}\text { Very substantial } \\
\text { pollution likely }\end{array}$ \\
\hline \multirow{2}{*}{ Winter } & MS & 61 & Moderate & 5.5 & Doubtful quality & 4.3 & Moderate pollution & 1.25 & Poor & 5.06 & Fair & $\begin{array}{l}\text { Fairly substantial } \\
\text { pollution likely }\end{array}$ \\
\hline & DS & 25 & Poor & 4.2 & Probable Moderate pollution & 3 & Severe pollution & 17.35 & Poor & 5.15 & Fair & $\begin{array}{l}\text { Fairly substantial } \\
\text { pollution likely }\end{array}$ \\
\hline \multirow{2}{*}{$\begin{array}{c}\text { Pre } \\
\text { monsoon }\end{array}$} & MS & 40 & Poor & 6.7 & Clean water & 5 & Moderate pollution & 14.63 & Poor & 5.5 & Fair & $\begin{array}{l}\text { Fairly substantial } \\
\text { pollution likely }\end{array}$ \\
\hline & DS & 42 & Moderate & 5.3 & Doubtful quality & 3 & Severe pollution & 2.5 & Poor & 5.5 & Fair & $\begin{array}{l}\text { Fairly substantial } \\
\text { pollution likely }\end{array}$ \\
\hline
\end{tabular}

Biological Monitoring Working Party (BMWP) score: $0-10=$ very poor, $11-40=$ poor, $41-70=$ moderate, $71-100=$ good, $>100=$ very good. Average Score Per Taxon $($ ASPT) score: $>6=$ clean water, $5-6=$ doubtful quality, $4-5=$ probable moderate pollution, $<4=$ probable severe pollution. Stream Invertebrate Grade Number-Average Level (SIGNAL) score: $>6=$ healthy habitat, $5-6=$ mild pollution, $4-5=$ moderate pollution, $<4=$ severe pollution. $\%$ EPT: $\leq 1=$ poor, $2-5=$ moderate, $>5=$ good. Midstream $($ MS), Downstream (DS). 


\section{Conclusions}

This is a first study on aquatic insect community of River Jatinga and their role in biomonitoring of river health. Computation of different biotic indices revealed that water quality is mostly moderate in the midstream while poor in the downstream of the river. The study further confirmed the role of aquatic insects as bioindicators in the lotic systems and the significance of use of different biotic indices in discerning water quality. It is recommended that for water quality management of rivers or streams, distribution of aquatic insect communities in different sites and seasons can be used in biomonitoring study. Future studies on this river would pinpoint the sources of pollution and also provide insight to the biodiversity of the river.

\section{Compliance with Ethical Standard}

Conflict of interests: The authors declare that for this article they have no actual, potential or perceived conflict of interests.

Ethics committee approval: -

Funding disclosure: -

Acknowledgments: Authors thank Department of Ecology and Environmental Science, Assam University, Silchar for providing necessary laboratory facilities. First author is thankful to the University for providing Institutional fellowship (non-NET).

Disclosure: -

\section{References}

Aazami, J., KianiMehr, N., Zamani, A. (2019). Ecological water health assessment using benthic macroinvertebrate communities (case study: the Ghezel Ozan River in Zanjan Province, Iran). Environmental Monitoring and Assessment, 191, 1-9.

https://doi.org/10.1007/s10661-019-7894-1

Aazami, J., Maghsodlo, H., Mira, S.S., Valikhani, H. (2020). Health evaluation of riverine ecosystems using aquatic macroinvertbrates: a case study of Mohammad-Abad River Iran. International Journal of Environmental Science and Technology, 17, 2637-2644.

https://doi.org/10.1007/s13762-020-02658-4

Adu, B.W., Oyeniyi, E.A. (2019). Water quality parameters and aquatic insect diversity in Aahoo stream, southwestern Nigeria. The Journal of Basic and Applied Zoology, 80(15), 2-9.

https://doi.org/10.1186/s41936-019-0085-3
Akyildiz, G.K., Duran, M. (2021). Evaluation of the impact of heterogeneous environmental pollutants on benthic macroinvertebrates and water quality by long-term monitoring of the Buyuk Menderes river basin. Environmental Monitoring and Assessment, 193(5), 280.

https://doi.org/10.1007/s10661-021-08981-8

Arthington, A.H., Naiman, R.J., McClain, M.E., Nilsson, C. (2010). Preserving the biodiversity and ecological services of rivers: new challenges and opportunities. Freshwater Biology, 55, 1-16.

https://doi.org/10.1111/j.1365-2427.2009.02340.x

Arunachalam, M., Nair, K.C.M., Vijverberg, J., Kortmulder, K., and Suriyanarayanan, H. (1991). Substrate selection and seasonal variation in densities of invertebrates in stream pools of a tropical river. Hydrobiologia, 213, 141-148. https://doi.org/10.1007/BF00015000

Azmi, W.A., Hussin, N.H., Amin, N.M. (2018). Monitoring of water quality using aquatic insects as biological indicators in three streams of Terengganu. Journal of Sustainability Science and Management, 13, 67-76.

Barathy, S., Sivaruban, T., Arunachalam, M., Srinivasan, P. (2021). Community structure of Mayflies (Insecta: Ephemeroptera) in tropical streams of Western Ghats of Southern India. Aquatic Research, 4(1), 21-37. https://doi.org/10.3153/AR21003

Barman, B., Gupta, S. (2015). Aquatic insects as bio-indicator of water quality- A study on Bakuamari stream, Chakrashila Wildlife Sanctuary, Assam, North East India. Journal of Entomology and Zoology Studies, 3, 178-186.

Bhattacharya, R.K., Chatterjee, N.D., Dolui, G. (2019). Consequences of sand mining on water quality and instream biota an alluvial stream: a case-specific study in South Bengal River, India. Sustainable Water Resources Management, 5, 1815-1832.

Birk, S., Bonne, W., Borja, A., Brucet, S., Courrat, A., Poikane, S., Solimini, A., van de Bund, W.V., Zampoukas, N., Hering, D. (2012). Three hundred ways to assess Europe's surface waters: An almost complete overview of biological methods to implement the Water Framework Directive. Ecological Indicator, 18, 31-41. https://doi.org/10.1016/j.ecolind.2011.10.009.

Boonsoong, B., Braasch, D. (2013). Heptageniidae (Insecta, Ephemeroptera) of Thailand. Zookeys, 272, 61-93. 
Bouchard, R.W. (2009). Guide to aquatic invertebrate families of Mongolia identification manual for students, citizen monitors, and aquatic resource professionals. Chironomidae research group, University of Minnesota.

Brasil, L.S., Juen, L., Batista, J.D., Pavan, M.G., Cabette, H.S.R. (2014). Longitudinal distribution of the functional feeding groups of aquatic insects in streams of the Brazilian Cerrado Savanna. Neotropical Entomology, 43, 421-428. https://doi.org/10.1007/s13744-014-0234-9

Brittain, J.E. (1974). Studies on the lentic Ephemeroptera and Plecoptera of southern Norway. Norskent Tidsskrift, 21, $135-151$.

Carter, J.L., Resh, V.H., Morgan, J.H. (2017). Macroinvertebrates as biotic indicators of environmental quality. In: Lamberti, G.A., Hauer, F.R. (Eds.), Methods in stream ecology (Third edition). Academic Press. 293-318.

https://doi.org/10.1016/B978-0-12-813047-6.00016-4

Chaw, V.V., Harun, S., Hee, K.B., Hui, A.W.B., Fikri, A.H. (2018). Aquatic insect and water quality study at Kimanis River, Crocker Range National Park, Sabah, Malaysia. Journal of Tropical Biology and Conservation, 15, 223-245.

Chessman, B. (2003). SIGNAL2- a scoring system for macroinvertebrate ('water bugs') in Australian rivers. Monitoring River Health Initiative Technical Report number 31, Canberra: Commonwealth of Australia, 32. ISBN: 0642548978

Choate, P.M. (2003). Identification of Beetles (Coleoptera). Department Entomology and Nematology University of Florida, 1-12.

Engelmann, H.D. (1978). Zur dominanzklassifikazierung von bodenarthropoden. Pedobiologia, 18, 378-380.

Eriksen, T.E., Brittain, J.E., Søli, G., Jacobsen, D., Goethals, P., Friberg, N. (2021). A global perspective on the application of riverine macroinvertebrates as biological indicators in Africa, South-Central America, Mexico and Southern Asia, Ecological Indicators, 126, 1-17.

https://doi.org/10.1016/j.ecolind.2021.107609

FSI (2019). India State Forest Report; Assam. Government of India. https://fsi.nic.in/isfr19/vol2/isfr-2019-vol-ii-assam.pdf (accessed on April 16, 2020).

Ganguly, I., Patnaik, L., Nayak, S. (2018). Macroinvertebrates and its impact in assessing water quality of riverine system: A case study of Mahanadi River, Cuttack, India, Journal of Applied and Natural Science, 10 (3), 958-963. https://doi.org/10.31018/jans.v10i3.1817

Gupta, A., Michael, R.G. (1983). Seasonal differences and relative abundance among populations of benthic aquatic insects in a moderately high altitude stream. Proc. Wkshp. High Alt. Ent. and Wildl. Ecol. Zool. Surv. India, 21-38.

Habib, S., Yousuf, A.R. (2012). Benthic macroinvertebrate community of Yousmarg streams (Doodganga stream and Khanshah Manshah canal) in Kashmir Himalaya, India. Journal of Ecology and the Natural Environment, 4, 280-289. https://doi.org/10.5897/JENE12.014

Hellawell, J.M. (1986). Biological indicators of freshwater pollution and environmental management. In: Melanby K, Editor, Pollution Monitoring Series, New York: Elsevier Science Publisher Ltd., 1-558.

https://doi.org/10.1007/978-94-009-4315-5

Hilsenhoff, W.L. (1988). Rapid field assessment of organic pollution with a famiy-level biotic index. Journal of the North American Benthological Society, 7, 65-68.

https://doi.org/10.2307/1467832

Lenat, D.R., Smock, A., Penrose, D.L. (1980). Use of benthic macroinvertebrates as indicators of environmental quality, Biological monitoring for environmental effects, Lexington books, Toronto, 97-114. ISBN: 0669033065

Li, L., Zheng, B., Liu, L. (2010). Biomonitoring and bioindicators used for River ecosystems: Definitions, approaches and trends. Procedia Environmental Sciences, 2, 1510-1524. https://doi.org/10.1016/i.proenv.2010.10.164.

Mahmoud, M.A., Riad, S.A. (2020). Ecological studies on some aquatic insects in the Damietta branch, River Nile of Egypt as bioindicators of pollution. Egyptian Journal of Aquatic Biology and Fisheries, 24(4), 57-76.

https://doi.org/10.21608/EJABF.202095322

Mandaville, S.M. (2002). Benthic macroinvertebrates in freshwaters-taxa tolerance values, metrics, and protocols. Soil and Water Conservation Society of Metro Halifax, Nova Scotia.

Marsese, F.O., Kitaka, N., Kipkemboi, J., Gettel, G.M., Irvine, K., Mc Clain, M.E. (2014). Macroinvertebrate functional feeding groups in Kenyan highland streams: evidence 
for a diverse shredder guild. Freshwater Science, 33, 435450.

https://doi.org/10.1086/675681

Marwein, I., Gupta, S. (2018). Aquatic insects as indicator of water quality: A study on a small stream of Shillong, Meghalaya, North-East India. Indian Journal of Ecology, 45, 511-517.

Merritt, R.W., Cummins, K.W. (1996). An introduction to the aquatic insects of North America. $3^{\text {rd }}$ ed. Kendall/Hunt, Dubuque, I.A., 862. ISBN: 978-0787232412

Meyer, J.L., Sale, M.J., Mulholland, P.J., Poff, N.L. (1999). Impacts of climate change on aquatic ecosystem functioning and health, Journal of the American Water Resources Association, 35, 1373-1386.

https://doi.org/10.1111/j.1752-1688.1999.tb04222.x

Musonge, P.S., Boets, P., Lock, K., Ambarita, M.N.D., Forio, M.A.E., and Goethals, P.L. (2020)._Rwenzori Score (RS): A benthic macroinvertebrate index for biomonitoring rivers and streams in the Rwenzori region, Ugenda, Sustainability, 12, 10473.

https://doi.org/10.3390/su122410473

Mustow, S.E. (2002). Biological monitoring of rivers in Thailand: Use and adaptation of the BMWP score. Hydrobiologia , 479, 191-229.

Oertel, N., Salanki, J. (2003). Biomonitoring and bioindicators in aquatic ecosystems. In:Ambasht RS and Ambasht NK (Eds.), Modern trends in applied aquatic ecology, Kluwer/Academic Plennum Publishers, New York, 219-246. https://doi.org/10.1007/978-1-4615-0221-0 10

Pennak, R.W. (1978). Freshwater invertebrates of the United States. $2^{\text {nd }}$ ed. John Wiley and Sons, New York City, 803. https://doi.org/10.4319/Io.1980.25.2.0383a

Rosenberg, D.M., Resh, V.H. (1993). Introduction to freshwater biomonitoring and benthic macroinvertebrates. In: Rosenberg, DM and Resh, VH, Editors, Freshwater biomonitring and benthic macroinvertebrates: Chapman and Hall, New York, 1-9. ISBN: 0412022516
Sandin, L., Johnson, R.K. (2000). The statistical power of selected indicator metrics using macroinvertebrates for assessing acidification and eutrophication of running waters. Hydrobiologia, 422, 233-243.

https://doi.org/10.1023/A:1017082619481

Stonedahl, G.M., Lattin, J.D. (1982). The Gerridae or Water Striders of Oregon and Washington (Hemiptera: Heteroptera). Agric. Expt. Sta. Tech. Bull. 144, Oregon State University Corvallis, Oregon, 36.

Subramanian, K.A., Sivaramakrishnan, K.G. (2005). Habitat and microhabitat distribution of stream insect communities of the Western Ghats. Current Science, 89, 976-987.

Subramanian, K.A., Sivaramakrishnan, K.G. (2007). Aquatic Insects for Biomonitoring Freshwater Ecosystems-A Methodology Manual. Ashoka Trust for Ecology and Environment (ATREE), Bangalore, India, 31.

Takhelmaym, K., Gupta, S., Singh, N.R. (2013). Diversity and density of aquatic insects in the lower reach of River Moirang, Manipur, North East India. Proceedings of the $\mathrm{Na}$ tional Academy of Sciences, India Section B: Biological Sciences, 83, 575-584.

https://doi.org/10.1007/s40011-013-0166-x

Thirumalai, G. (1999). Aquatic and semi-aquatic Heteroptera of India. Indian Association of Aquatic Biologists, Hyderabad, 7, 1-74.

Turkmen, G., Kazanci, N. (2010). Applications of biodiversity indices to benthic macroinvertebrate assemblages in streams of a national park in Turkey. Review of Hydrobiology, 3 (2), 111-125.

Wahizatul, A.A., Long, S.H., Ahmed, A. (2011). Composition and distribution of aquatic insect communities in relation to water quality in two freshwaters streams of Hulu Terengganu, Terngganu. Journal of Sustainability Science and Management, 6, 148-155. 